\title{
Effect of some growth regulators on fruit quality of Tamr date cultivar
}

\section{H. A. Mahdy}

Horticulture Research Institute, Agricultural Research Centre, Cairo, Egypt

\begin{abstract}
HE effect of gibberellic acid $\left(\mathrm{GA}_{3}\right)$, naphthalene ascetic acid (NAA), benzyl adenine (BA) and salicylic acid (SA) at different concentrations on bunch weight, fruit quality and harvest date of date palms (Tamr cv.) was studied for two successive seasons (2013 \& 2014) at a commercial orchard in Dakhla oasis, El-Wady El-Gadid Governorate, Egypt . In general, all treatments significantly increased the bunch weight and fruit physical properties as compared with control. Best results were achieved by $\mathrm{GA}_{3}$ at $150 \mathrm{ppm}$ followed by NAA at $150 \mathrm{ppm}$ when sprayed two times (at 4 and 8 weeks after pollination), represented in increasing bunch weight, fruit weight and dimension and flesh weight percentage with high content of TSS, reducing sugars and total sugars. While the lowest fruit content of TSS, total and reducing sugars were obtained with SA application as compared with other treatments or untreated one (control). On the other hand all tested growth regulators delayed harvesting. Tamr dates were harvested with a delay between 5 and 23 days when bunches sprayed with BA and NAA, respectively

Thus, the most beneficial treatment in this trial concern is $\mathrm{GA}_{3}$ at $150 \mathrm{ppm}, 4$ and 8 weeks after pollination, which produced heaviest bunch weight and high fruit weight and dimensions and flesh weight percentage with high content of TSS, total and reducing sugars (which meaning high fruit quality) and could be considered as a recommended treatment under the conditions of this experiment.
\end{abstract}

Keywords: Date palm, Growth regulators, Fruit quality, GA, NAA, BA, SA.

Egypt could be considered as one of the major date producing countries in the world with 1414000 tons (FAO, 2012). Date palm (Phoenix dactylifera L.) is grown in Nile Valley and desert districts. About two hundred different date cultivars are known, of these only a few are important. Tamr date cultiv ar is one of the most important cultivar of dry dates group in El-Wady El- Gaded Governorate, Egypt and demanded in local market for its good quality. For these reasons it is very important to try different treatments aiming to improve its fruit quality. Plant growth regulators play an important role in regulating fruit growth and development. Some of these substances were used in controlling ripening date as well as improving the fruit quality, which act for increasing the income of farmer. Findings from implemented studies revealed that NAA increased increased fruit size, weight and delayed ripening of dates (Aboutalebi \& 
Hasanzadah, 2007, Kassem et al., 2010 and Moustafa et al., 1996). Spraying NAA and $\mathrm{GA}_{3}$, affected fruit retained percentage, bunch weight and fruit quality as well as fruit contents of T.S.S., total sugars and reducing sugars of date palm cultivars (Al-Qurash et al., 2012). The cytokinins are plant growth regulators that enhance plant cell division and cell expansion, spraying $75 \mathrm{ppm}$ of cytophex increased fruit and flesh weight, fruit length and diameter of Samany and Zaghloul fruits (El-Kosary, 2009). Salicylic acid (SA) is a simple phenolic compound it is recognized as plant growth regulators, because of its external application effect on many plant growth physiological processes (Akhodart, 2004). The effect of growth regulators on yield and fruit quality of date palm has been reported by El-Makhtoun et al. (1995), Moustafa et al. (1996), Al-Kalifah et al. (2007), Aboutalebi \& Hasanzadah (2007), Harhash \& Al-Obeed (2007), Soliman (2007), Tavakkoli et al. (2007), Abdolali \& Abdi (2010) and Al-Obeed (2010). The main objectives of the present work were to study the effect of growth regulators, gebberellic acid $\left(\mathrm{GA}_{3}\right)$, naphthalene ascetic acid (NAA), benzyl adenine (BA) and salicylic acid (SA) at different rates on harvest date, bunch weight and fruit quality of Tamr date cultivar.

\section{Materials and Methods}

The present study was conducted through two successive seasons (2013 and 2014) on Tamr date palms (dry cultivar) grown in sandy soil at a commercial orchard in Dakhla oasis, El-Wady El-Gadid Governorate, Egypt. Palms were about 12 years old planted at $7 \times 7$ meter apart and subjected to the common cultural practices. Only nine bunches of nearly equal size were left on each palm, these bunches were pollinated by using pollen grains from the same male palm in both seasons. Four palms were selected as uniform as possible for this study. Nine treatments were applied on the same four selected palm trees, each treatment had four replication each replicate was represented by one bunch. Eight treatments of gibberellic acid $\mathrm{GA}_{3}$ at $100 \& 150 \mathrm{ppm}$, naphthalene ascetic acid (NAA) at $100 \& 150 \mathrm{ppm}$, benzyl adenine (BA) at $50 \& 100 \mathrm{ppm}$ and salicylic acid (SA) at $50 \& 100 \mathrm{ppm}$ were sprayed as well as the control which sprayed with tap water. Spraying was done in early morning with a hand sprayer. The application of growth regulators was done twice at 4 and 8 weeks after pollination in both seasons to determine the effect of these substances on bunch weight, fruit quality and harvest date of date palms (Tamr cv.)

At picking time (all bunches were harvested when 75 percent of fruits were on tamar stage), bunch weight $(\mathrm{kg})$ was recorded. Sampling of 20 fruits was randomly selected from each replicate to study different physical properties including weight of fruit and seed, pulp (flush) weight $\%$ and fruit dimension. Total soluble solids (TSS), acidity, total and reducing sugars content were also determined according to the methods of A.O.A.C (2000). 
The obtained data were subjected to analysis of variance in randomized complete block design according to Snedecor and Cochran (1980) and new L.S.D. (0.05) was used for comparison (Waller and Duncan, 1969).

\section{Results and Discussion}

Date of harvesting and bunch weight:

Results of both seasons Table 1 reveal that all tested growth regulators delayed harvesting. Tamr dates were harvested delay 5-7 days when bunches sprayed with BA followed by SA (10-11 days) and $\mathrm{GA}_{3}$ treatments (16-19 days), while harvesting date was prolonged by $20-23$ days when bunches sprayed with NAA. These results are in agreement with Kassem et. al.,2010 who founded that the harvest was delayed by one month with NAA, GA 3 , three weeks with SA and by two weeks with BA.

Regarding bunch weight the same table show that all tested treatments significantly increased the average of bunch weight than that of the control. The highest bunch weight was obtained with $\mathrm{GA}_{3}$ at $150 \mathrm{ppm}(12.43 \& 12.72 \mathrm{~kg})$ followed by $\mathrm{GA}_{3}$ at $100 \mathrm{ppm}(11.86 \& 12.14 \mathrm{~kg})$ and $\mathrm{BA}$ at $100 \mathrm{ppm}(11.50 \&$ $12.04 \mathrm{~kg})$, whereas, the lowest bunch weight was recorded by un-treated bunches $(7.76 \& 8.13 \mathrm{~kg})$ in the first and second seasons, respectively. Bunch weight was not affected by different rates of all tested growth regulators. In other words, no significant differences were detected in this respect between the two levels of all growth regulators treatments. This was true in the two seasons of study. These results are in agreement with those reported by El- Makhtoun et al. (1995), Moustafa et al. (1996), Tavakkoli et al. (2007), El-Kosary (2009) and Al- Obeed et al. (2010).

TABLE 1. Effect of some growth regulators on bunch weight $(\mathrm{kg})$ and date of harvesting of Tamr date cv. during 2013 and 2014 seasons.

\begin{tabular}{|l|c|c|c|c|}
\hline \multirow{2}{*}{ Treatments } & \multicolumn{2}{|c|}{ Harvesting date } & \multicolumn{2}{c|}{ Bunch weight (kg) } \\
\cline { 2 - 5 } & 2013 season & 2014 season & 2013 season & 2014 season \\
\hline control & $5 / 11$ & $10 / 11$ & 7.76 & 8.13 \\
\hline $\mathrm{GA}_{3}$ at $100 \mathrm{ppm}$ & $21 / 11$ & $27 / 11$ & 11.86 & 12.14 \\
\hline $\mathrm{GA}_{3}$ at $150 \mathrm{ppm}$ & $22 / 11$ & $29 / 11$ & 12.43 & 12.72 \\
\hline NAA at $100 \mathrm{ppm}$ & $25 / 11$ & $2 / 12$ & 10.00 & 10.50 \\
\hline NAA at $150 \mathrm{ppm}$ & $27 / 11$ & $3 / 12$ & 10.50 & 11.34 \\
\hline BA at $50 \mathrm{ppm}$ & $11 / 11$ & $17 / 11$ & 11.00 & 11.60 \\
\hline BA at $100 \mathrm{ppm}$ & $10 / 11$ & $17 / 11$ & 11.50 & 12.04 \\
\hline SA at $50 \mathrm{ppm}$ & $16 / 11$ & $21 / 11$ & 9.00 & 9.78 \\
\hline SA at $100 \mathrm{ppm}$ & $16 / 11$ & $20 / 11$ & 9.82 & 10.17 \\
\hline
\end{tabular}

Fruit physical properties:

Tables $2 \& 3$ show that all tested growth regulators significantly increased the average fruit weight, fruit dimension and pulp weight percentage of Tamr dates as compared with the control. Fruit physical characteristics of Tamr date 
palm were higher at the high rate of tested growth regulators was more effective than the low rate but these differences did not reach the level of significance except $\mathrm{GA}_{3}$ treatment. Best results in fruit weight were achieved when bunches sprayed two times (at 4 and 8 weeks after pollination) by $\mathrm{GA}_{3}$ at $150 \mathrm{ppm}(13.96$ \& $13.90 \mathrm{gm})$ followed by NAA at $150 \mathrm{ppm}(12.73 \& 13.00 \mathrm{gm})$ and BA at 100 ppm (12.01 \& $12.35 \mathrm{gm})$ as compared with the control which produced the smallest fruit weight $(8.02 \& 8.34 \mathrm{gm})$ in the first and second seasons, respectively.

In regard to seed weight the obtained data revealed that there are no significant differences in seed weight between different growth regulators including the control, this was true in the two experimental seasons. In other words, the increase in fruit weight by tested treatments could be mainly attributed to the increase in pulp weight without regard to the changes of seed weight.

Regarding pulp weight percentage the same tables show that the same trends as observed in fruit weight, i.e. the tested treatments significantly increased the pulp weight $\%$ as compared with the control. The upper most values were obtained by $\mathrm{GA}_{3}$ at $150 \mathrm{ppm}(90.40 \& 90.93 \%)$ followed by NAA at $150 \mathrm{ppm}$ $(89.99 \& 90.00 \%)$ and BA at $100 \mathrm{ppm}(89.34 \& 90.28 \%)$ as compared with the control $(82.54 \& 84.41 \%)$ in the first and second seasons, respectively.

As for fruit dimension data reveal a nearly similar trend as discussed for fruit weight. Growth regulators significantly increased both fruit length and diameter as compared with the control in both seasons. Significant differences were detected between various treatments and the increase in fruit dimension. $\mathrm{GA}_{3}$ at $150 \mathrm{ppm}$ was the most effective in increasing fruit dimension as compared with other growth regulators in the two seasons of the study. The improvement in fruit physical properties as a result of growth regulators treatments might be due to their influence in enlarging the cells size and enhancing the strength of carbohydrate sink, thus increasing fruit size and weight (Al-Obeed, 2010). These results are in harmony with the findings of many scientists for several date cultivars (El-Makhtoun et al., 1995, Stern et al., 2006, Aboutalebi \& Hasanzadah, 2007, Soliman, 2007, Al-Obeed, 2010, Al-Quash et al., 2012 and El-Kosary, 2009), they found that growth regulators increased date fruit growth and improved fruit physical properties.

\section{Fruit chemical properties}

The results presented in Tables $4 \& 5$ indicate that in both seasons the studied treatments of growth regulators except BA and SA caused a significant increase in fruit content of T.S.S as compared with the control. Fruits produced from bunches sprayed by $\mathrm{GA}_{3}$ at $150 \mathrm{ppm}$ contained significantly higher TSS (79.21 \& $73.40 \%)$ than those produced from other treatments. On the other hand application of SA at $100 \mathrm{ppm}$ significantly decreased TSS $(66.00 \& 62.00 \%)$ as compared with the control (70.40 \& 66.00\%), this was true in the two seasons.

Egypt. J. Hort. Vol. 42, No. 1 (2015) 
EFFECT OF SOME GROWTH REGULATORS ON FRUIT QUALITY...

TABLE 2. Effect of some growth regulators on fruit physical properties of Tamr date cv. during 2013 seasons.

\begin{tabular}{|l|c|c|c|c|c|}
\hline Treatments & $\begin{array}{c}\text { Fruit } \\
\text { weight } \\
(\mathbf{g m})\end{array}$ & $\begin{array}{c}\text { Fruit } \\
\text { iength } \\
(\mathbf{c m})\end{array}$ & $\begin{array}{c}\text { Fruit } \\
\text { diameter } \\
(\mathbf{c m})\end{array}$ & $\begin{array}{c}\text { Pulp } \\
\text { weight } \\
\text { \% }\end{array}$ & $\begin{array}{c}\text { Seed } \\
\text { weight } \\
(\mathbf{g m})\end{array}$ \\
\hline Control & 8.02 & 3.80 & 2.40 & 82.54 & 1.40 \\
\hline GA3 at $100 \mathrm{ppm}$ & 12.44 & 4.40 & 3.29 & 88.91 & 1.38 \\
\hline GA3 at $150 \mathrm{ppm}$ & 13.96 & 4.90 & 3.48 & 90.40 & 1.34 \\
\hline NAA at $100 \mathrm{ppm}$ & 11.59 & 4.25 & 3.04 & 88.09 & 1.38 \\
\hline NAA at $150 \mathrm{ppm}$ & 12.73 & 4.50 & 3.23 & 89.00 & 1.40 \\
\hline BA at 50 ppm & 11.50 & 4.14 & 3.01 & 88.08 & 1.37 \\
\hline BA at $100 \mathrm{ppm}$ & 12.01 & 4.30 & 3.14 & 89.34 & 1.28 \\
\hline SA at 50 ppm & 9.32 & 4.04 & 2.80 & 85.30 & 1.37 \\
\hline SA at $100 \mathrm{ppm}$ & 9.70 & 4.16. & 2.94 & 85.97 & 1.36 \\
\hline New L.S.D. at 0.05 & 1.42 & 0.35 & 0.42 & 1.12 & N.S. \\
\hline
\end{tabular}

TABLE 3. Effect of some growth regulators on fruit physical properties of Tamr date cv. during 2014 seasons.

\begin{tabular}{|l|c|c|c|c|c|}
\hline Treatments & $\begin{array}{c}\text { Fruit } \\
\text { weight } \\
(\mathbf{g m})\end{array}$ & $\begin{array}{c}\text { Fruit } \\
\text { length } \\
(\mathbf{c m})\end{array}$ & $\begin{array}{c}\text { Fruit } \\
\text { diameter } \\
(\mathbf{c m})\end{array}$ & $\begin{array}{c}\text { Pulp } \\
\text { weight \% }\end{array}$ & $\begin{array}{c}\text { Seed } \\
\text { weight } \\
(\mathbf{g m})\end{array}$ \\
\hline Control & 8.34 & 3.91 & 2.65 & 84.41 & 1.30 \\
\hline GA3 at $100 \mathrm{ppm}$ & 12.66 & 4.40 & 3.44 & 89.96 & 1.27 \\
\hline GA3 at $150 \mathrm{ppm}$ & 13.90 & 4.90 & 3.59 & 90.93 & 1.26 \\
\hline NAA at $100 \mathrm{ppm}$ & 11.80 & 4.30 & 3.24 & 89.23 & 1.27 \\
\hline NAA at $150 \mathrm{ppm}$ & 13.00 & 4.60 & 3.36 & 90.00 & 1.30 \\
\hline BA at 50 ppm & 11.75 & 4.20 & 3.20 & 89.19 & 1.27 \\
\hline BA at $100 \mathrm{ppm}$ & 12.35 & 4.38 & 3.30 & 90.28 & 1.20 \\
\hline SA at 50 ppm & 9.70 & 4.15 & 2.95 & 87.01 & 1.26 \\
\hline SA at $100 \mathrm{ppm}$ & 10.24 & 4.20. & 3.08 & 87.69 & 1.26 \\
\hline New L.S.D. at 0.05 & 1.53 & 0.31 & 0.38 & 1.14 & N.S. \\
\hline
\end{tabular}

On the other hand the obtained data in the same table show there are no significant differences in fruit acidity between different growth regulators including the control, this was true in the two studied seasons.

Regarding total and reducing sugars content in fruits the data show that the same trends as observed in TSS, i.e. the highest values of total and reducing sugars were obtained by $\mathrm{GA}_{3}$ at $150 \mathrm{ppm}(67.34 .63 .35 \& 43.40,39.50 \%)$ followed by NAA at $150 \mathrm{ppm}(65.42 .60 .50 \& 41.40,37.50 \%)$ as compared with the control (58.63, $53.62 \& 34.10 .30 .20 \%)$ in the first and second seasons, respectively. The obtained data show also that there are significant differences between tested rates of $\mathrm{GA}_{3}$ and NAA. fruits produced from bunches sprayed with $\mathrm{GA}_{3}$ or NAA at $150 \mathrm{ppm}$ ( high rate) contained significantly higher total and reducing sugars than produced from $\mathrm{GA}_{3}$ or NAA at $100 \mathrm{ppm}$ (low rate). 
The lowest values in this respect were recorded in fruits produced frombunches sprayed with SA at two tested rates while BA treatments gave similar values of total and reducing sugars as the control.

Results also show that the most of these sugars were found as reducing sugars. These results are in accordance with the findings of other investigators (El- Makhtoun et al., 1995, Harhash \& Al-Obeed, 2007, Tavakkoli et al., 2007, El-Kosary, 2009, Al- Obeed et al., 2010 and Abdolali \& Abdi, 2010).

TABLE 4. Effect of some growth regulators on fruit chemical properties of Tamr date cv. during 2013 seasons.

\begin{tabular}{|l|c|c|c|c|c|}
\hline Treatments & TSS \% & Acidity \% & $\begin{array}{c}\text { Reducing } \\
\text { sugars \% }\end{array}$ & $\begin{array}{c}\text { Non } \\
\text { reducing } \\
\text { sugars } \\
\text { \% }\end{array}$ & $\begin{array}{c}\text { Total } \\
\text { sugars\% }\end{array}$ \\
\hline Control & 70.40 & 0.46 & 34.10 & 24.53 & 58.63 \\
\hline GA3 at $100 \mathrm{ppm}$ & 77.77 & 0.44 & 37.90 & 24.01 & 61.91 \\
\hline GA3 at $150 \mathrm{ppm}$ & 79.21 & 0.47 & 43.40 & 23.94 & 67.34 \\
\hline NAA at $100 \mathrm{ppm}$ & 74.29 & 0.47 & 36.80 & 24.24 & 61.04 \\
\hline NAA at $150 \mathrm{ppm}$ & 77.80 & 0.49 & 41.40 & 24.02 & 65.42 \\
\hline BA at 50 ppm & 71.20 & 0.48 & 34.00 & 24.85 & 58.85 \\
\hline BA at $100 \mathrm{ppm}$ & 72.40 & 0.42 & 34.00 & 25.10 & 59.10 \\
\hline SA at 50 ppm & 68.40 & 0.49 & 32.00 & 25.00 & 57.00 \\
\hline SA at $100 \mathrm{ppm}$ & 66.00 & 0.54. & 30.50 & 25.43 & 55.93 \\
\hline New L.S.D. at 0.05 & 2.46 & N.S & 1.04 & 1.14 & 1.74. \\
\hline
\end{tabular}

TABLE 5. Effect of some growth regulators on fruit chemical properties of Tamr date cv. during 2014 seasons.

\begin{tabular}{|l|c|c|c|c|c|}
\hline Treatments & TSS \% & Acidity \% & $\begin{array}{c}\text { Reducing } \\
\text { sugars \% }\end{array}$ & $\begin{array}{c}\text { Non } \\
\text { reducing } \\
\text { sugars } \\
\text { \% }\end{array}$ & $\begin{array}{c}\text { Total } \\
\text { sugars\% }\end{array}$ \\
\hline Control & 66.00 & 0.36 & 30.20 & 23.42 & 53.62 \\
\hline GA3 at $100 \mathrm{ppm}$ & 71.00 & 0.38 & 33.80 & 23.00 & 56.80 \\
\hline GA3 at $150 \mathrm{ppm}$ & 73.40 & 0.40 & 39.50 & 22.85 & 62.35 \\
\hline NAA at $100 \mathrm{ppm}$ & 68.00 & 0.40 & 32.70 & 23.10 & 55.80 \\
\hline NAA at $150 \mathrm{ppm}$ & 72.40 & 0.38 & 37.50 & 23.00 & 60.50 \\
\hline BA at 50 ppm & 67.00 & 0.35 & 30.10 & 23.70 & 53.80 \\
\hline BA at $100 \mathrm{ppm}$ & 68.20 & 0.37 & 30.20 & 24.00 & 54.20 \\
\hline SA at 50 ppm & 64.50 & 0.39 & 28.00 & 24.00 & 52.00 \\
\hline SA at $100 \mathrm{ppm}$ & 62.00 & 0.41. & 28.40 & 24.34 & 52.74 \\
\hline New L.S.D. at 0.05 & 2.39 & N.S & 1.04 & 1.12 & 1.81 \\
\hline
\end{tabular}

Conclusively, the most beneficial treatment in this trial is $\mathrm{GA}_{3}$ at $150 \mathrm{ppm}, 4$ and 8 weeks after pollination, which produced the heaviest bunch weight and high fruit weight and dimensions and flesh weight percentage with high content of TSS and reducing and total sugars (which meaning high fruit quality) and

Egypt. J. Hort. Vol. 42, No. 1 (2015) 
could be considered as a recommended treatment under the conditions of this experiment.

\section{References}

A.O.A.C. (2000) "Official Methods of Analysis", $17^{\text {th }}$ ed., Association of Official Analy tical Chemistry, U.S.A.

Abdolali, H. and Abdi, G. (2010) Effect of some plant regulators on physiochemical characteristics of date palm (Phoenix dactylifera L.) cv. kabkab fruit. AmericanEurasian J. Agric. \& Environ, Sci., 7 (3), 277-282.

Aboutalebi, A. and Hasanzadah, H. (2007) Effect of plant growth regulators on date fruits characteristics. Proceeding of the fourth Symposium on date palm, Saudi Arabia,King Faisal Univ. Al- Hassa,5-8 May, pp.116.

Al-Kalifah, M., Hadi, S., Khan, F.A., Shanavaskhan, AE. and Askari, E. (2007) Effect of plant growth regulators on fruit abnormality (shees) of tissue culture derived date pale (phoenix dactylifera L.). Proceeding of the fourth Symposium on date palm, Saudi Arabia, King Faisal Univ. Al- Hassa,5-8 May, pp.163.

Akhodary, S.A. (2004) Effect of salicylic acid on the growth, photosynthesis and carbohy drate metabolism in salt stressed maize plants. Int. J. of Agric. and Biol., 6 (1), $1-8$.

Al- Obeed, R.S. (2010) Improving fruit quality, marketability and storageability of Barhee date palm. World Applied Sciences Journal, 9 (6), 630-637.

Al-Qurash, A.D., M.A., Awad, and Elsayed, M.I. (2012) Pre-harvest fruit drop, bunch weight and fruit quality of Rothana and Ghur date palm cultivars as affected by some growth regulators under hot arid conditions. American-Eurasian J. Agric. \& Environ, Sci., 12 (6), 781-789.

El-Kosary, S., (2009) Effect of NAA, GA 3 and Cytophex spraying on Samany and Zaghloul date palm yield, fruit retained and characteristics. Journal Hort. Sci. Ornamental Plant, 1 (2), 49-59.

EL-Makhton, F.M.B., Sabour, A.M.T. and Abdalla, M.Y. (1995) Effect of NAA on yield and quality of Zaghloul date fruits. Egypt, J. Abbl. Sci., 10 (9) 139-147.

F.A.O. (2012) Food and Agriculture Organization of the United Nations. http://faostat.foa.org

Harhash, M.M. and Al-Obeed, R.S. (2007) Effect of naphthalene acetic acid on yield and fruit quality of Barhee and Shahl Date Palm cultivars. Assiut J. Agric. Sci., 38 (2), 63-73. 
Kassem, H.A., Al-Obeed, R.S. and Ahmed, M.A. (2010) effect of plant growth regulators on quantities and qualitative treats of Shahani date (phoenix dacty lifera L.). fruits IV international date palm conference 2010. ISHS Acta Horticulture, 882

Moustafa, A.A., Seif, S.A. and Abou-El-Azayem, A.I. (1996) Date fruit response to naphthalene acetic acid. Proceeding of the third Symposium on the Date Palm in Saudi Arabia, January, 17-20, 369-378

Nawaz, M.A., Ahmed, W. Ahmed, S. and Khan, M. (2008) Role of growth regulators on preharvest fruit drop, yield and quality in Kinnow mandarin. Pakistan. J. Bot., 40 (5), 1971-1981

Snedecor, G.W. and Cochran W.G. (1980) "Statistical Methods" $7^{\text {th }}$ ed. Iowa State Univ. Press, Ames, Iowa, U.S.A., pp. 365-372.

Soliman, S.S. (2007) Effect of $\mathrm{GA}_{3}$ on yield and fruit characteristics of Sakkoty date palm under Aswan conditions. The fourth Symposium on Date Palm in King Faisal Univ. Al-Hassa, Saudi Arabia, 5-8 May, p. 111.

Stern, R.A., Ben Arie, R., Applebaum, S. and Flaishman, M. (2006) Cytokinins increase fruit size of Delicious and Golden Delicious (Malus domestica) apple in warm climate. J. Hort. Sci. Biotech., 18, 51-56.

Tavakkoli, A., Tafazoli, E. and Rahemi, M. (2007) Effect of Ethephon, Naphthalin acitic acid and seven on fruit characteristics of Shahani date (Phoenix dactylifera L.). The fourth Symposium on Date Palm in King Faisal Univ. Al-Hassa, Saudi Arabia, 58 May, p. 109.

Waller, R.A. and Duncan, D.B. (1969) A buyes rule for the symmetric multiple comparison problem. Amer. State Assoc. J., 64, 1484-1503.

Yuan, R. and Carbaugh, D. (2007) Effects of NNA, AVG and 1-MCP on ethylene biosynthesis, preharvest fruit drop, fruit maturity and quality of "Golden Supreme" and "Golden Delicious" apples. Hort. Sci., 42 (1), 101-105. 


\section{تأثثير بعض منظمات النمو على جودة ثمار البلح التمر \\ معهد عبد العزيز مهاتى معز البحوث الزر اعية ـ القاهرة - مصر.}

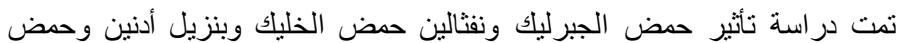

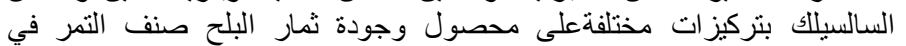

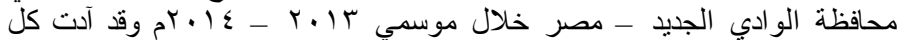

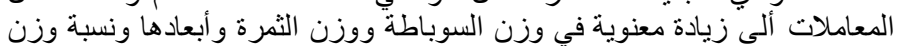
اللحم.

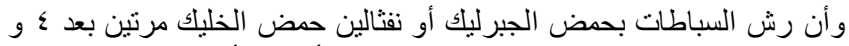

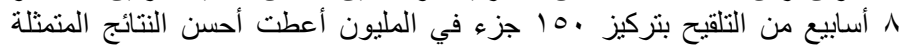

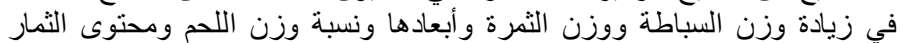

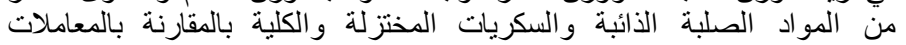

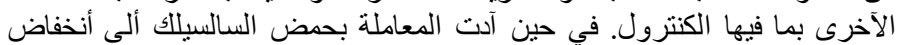

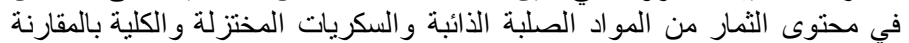

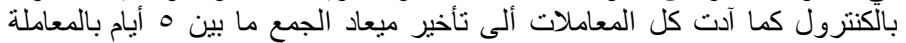

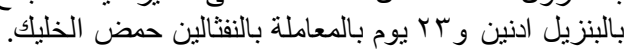

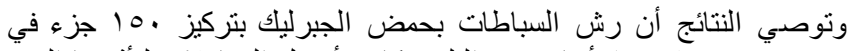

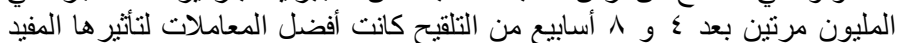
على زيادة وزن السباطة وجودة ثئمار البلح التمر. 